ORIGINAL ARTICLE

\title{
Influence of submerged macrophytes on phosphorus in a eutrophic reservoir in a semiarid region
}

\author{
Vanessa Virginia Barbosa*, Juliana dos Santos Severiano, Dayany Aguiar de Oliveira, José Etham de Lucena Barbosa \\ Laboratório de Ecologia Aquática (LEAq), Centro de Ciência e Tecnologia, Programa de Pós-graduação em Ciência e Tecnologia Ambiental, \\ Universidade Estadual da Paraíba, Rua Baraúnas 351, Bairro Universitário, Campina Grande, Paraíba, CEP 58429-500, Brazil
}

\begin{abstract}
Phosphorus (P) is the main nutrient responsible for the harmful effects caused by the enrichment of aquatic systems, and submerged macrophytes play an important role in this process, since they can both remove and release this nutrient in environmental compartments. The present study aimed to evaluate the influence of submerged macrophytes on $\mathrm{P}$ in the water, sediment, and water-sediment interface in a eutrophic reservoir in a semiarid region and to evaluate the relationship between the concentration of this nutrient in macrophyte tissue and that available in the different compartments. Were performed ten collection campaigns, in three reservoir locations: at the entrance of the Paraíba River; in the intermediate area between the river entrance and the dam and at the dam. We observed a difference in the P concentration inside and outside macrophyte banks, and this difference was determined by the abundance and intensity of macrophyte growth and decomposition. In sites with extensive vegetation banks and where decomposition was more intense, macrophytes released $\mathrm{P}$ to the water-sediment interface and sediment compartments. By contrast, in sites with smaller vegetation banks and where macrophytes did not show reduced abundance, $\mathrm{P}$ was removed from these compartments. The entry of new water originating from river water transfer was an important modifying factor of the physical and chemical characteristics and macrophyte abundance. The zone where the river enters the reservoir was the area most affected by the water transfer. The macrophyte decomposition in this zone resulted in the highest $\mathrm{P}$ concentration in the water-sediment interface and sediment compartments, which demonstrates the importance of macrophytes in the fertilization of water bodies and, consequently, in the eutrophication process. In turn, in the dam zone, where the macrophyte banks were more stable and without large variations in abundance, P was removed from the compartments. A relationship between $\mathrm{P}$ in macrophyte tissue and that available in the environment was observed, particularly at the water-sediment interface, indicating that this compartment was the main P source for these plants, which demonstrated that these plants store higher amounts of $\mathrm{P}$ in nutrient-rich sediment and water, functioning as an indicator of the nutritional status of a reservoir.
\end{abstract}

\section{INTRODUCTION}

Aquatic macrophytes are important primary producers in aquatic ecosystems that act in water quality regulation

Corresponding author: vanessav barbosa@hotmail.com

Key words: Macrophyte banks; Brazil; growth; decomposition; eutrophication; Egeria densa.

Edited by: Franco Tassi, Department of Earth Sciences, University of Florence, Italy.

Contributions: VVB, JSS, JELB, conceptualization; VVB, JSS DAO, data curation; VVB, DAO, formal analysis, methodology; JSS, JELB, resources, supervision; VVB, manuscript drafting; VVB, JSS, JELB, manuscript writing, review AND editing.

Conflict of interests: the authors declare no potential conflict of interests.

Received: 13 July 2019.

Accepted: 14 January 2020.

This work is licensed under a Creative Commons Attribution NonCommercial 4.0 License (CC BY-NC 4.0).

${ }^{\circ}$ Copyright: the Author(s), 2020

Licensee PAGEPress, Italy

J. Limnol., 2020; 79(2): 138-150

DOI: 10.4081/jlimnol.2020.1931 by removing nutrients or making them available (Zhang et al., 2016; Lu et al., 2018), thus playing a key role in eutrophication.

Eutrophication is a global problem that consists of an excessive supply of nutrients of anthropogenic origin to water bodies, and the main consequences include dissolved oxygen depletion, reduced water transparency, and increased toxic cyanobacterial biomass (Silvino and Barbosa, 2015; Huang et al., 2017; Huisman et al., 2018), which are harmful to human health (Hilbor and Beasley, 2015).

Phosphorus (P) is regarded as the main regulator of primary production in lakes and reservoirs and is considered the nutrient responsible for the negative effects associated with eutrophication (Correll, 1998; Schindler et al., 2016). The supply of P originates largely from external sources, whether point or diffuse sources (Carpenter et al., 1998; Huang et al., 2017); however, internal sources can also contribute significantly, especially when originating from sediment (Wu et al., 2013). Studies have shown that even with the reduction of external nutrient loads, sediment can act as an internal fertilization mechanism, releasing $\mathrm{P}$ to the water column (Lürling et al., 2016).

Macrophytes can improve the quality of eutrophic waters by removing nutrients and toxic metals from the water column by cellular uptake (Srivastava et al., 2008; Lone et al., 2014), thus functioning as deposits of chemical 
compounds (Moore et al., 2016). In the case of rooted macrophytes, nutrients are absorbed from both water and sediment (Li et al., 2015), and the use of macrophytes are therefore recommended as an important strategy in the recovery of eutrophic waters (Zeng et al., 2017). It is estimated that, by direct assimilation, these plants can remove up to $30 \%$ of P from the water column, whereas this value can reach 25\% in sediment (Li et al., 2015). Macrophytes also attenuate wind and current action, reducing the resuspension of $\mathrm{P}$ in the sediment, thus rendering it unavailable to the water column (Holmroos et al., 2014).

The presence of macrophytes can also result in increased nutrient availability and reduced quality of the aquatic system, as nutrients are released into the water column by macrophyte decomposition (Bianchini-Junior et al., 2014; Levi et al., 2015). Moreover, submerged macrophytes can indirectly increase P flow, particularly in the sediment-water interface, by causing an increase in pH due to photosynthetic activity (Wu et al., 2013; Zhang et al., 2016).

Egeria densa is a submerged macrophyte with wide geographical distribution, this species has been reported in South America and southern Africa, spreading over temperate regions in recent decades (Chamier et al. 2012), such distribution is determined by environmental factors as nutrient availability (Lu et al., 2018). Several studies have found a relationship between Egeria densa and nutrient availability in water and sediment, especially phosphorus (Carignan and Kalff, 1980; Feijoó et al.,2002; Li et al., 2018). Egeria densa is a macrophyte characterized by a high surface area, thus forming deep-rooted dense underwater vegetable banks (Vanderstukken et al., 2011). Since these plants may account for a significant fraction of total biomass in lakes with extensive coastal areas (Wetzel, 1975), the phosphorus budgets of this environment can be strongly affected by the nutrition of these plants.

The factors that determine nutrient removal and release by macrophytes are directly related to the growth and decomposition of these plants (Barbosa et al., 2017; Lu et al., 2018). In temperate regions, macrophyte cycles and associated biogeochemical flows follow an annual cycle, but there is no consensus on these processes in the tropics (Carpenter and Lodge, 1986; Ferreira et al., 2018), especially in reservoirs in semiarid regions. In these areas, reservoirs are mostly shallow and are influenced by the low rainfall rates and high evaporation rates characteristic of semiarid regions (Barbosa et al., 2012). The nutrient concentrations tend to be high, as well as the sediment resuspension by wind and wave action, particularly in drought periods, when the water level is markedly reduced (Mosley, 2015; Rocha Junior et al., 2018).

Submerged macrophytes are influenced by fluctuations in water level, which is considered the most important physical process causing variations in the extension of macrophyte cover and, consequently, in nutrient cycling in coastal areas (Lu et al., 2018). The main pathway of phosphorus absorption in submerged macrophytes is through the root pathway, which is able to fully meet the nutritional needs (Barko and Smart, 1980; Feijoó et al., 2002). Although the leaves also have this property, depending on the concentrations in the water, this pathway is slower and less efficient (Gabrielson et al., 1984). These aquatic plants, the process of translocation is also very common which refers to the transport of nutrients from the roots towards the shoots (Wallsten, 1980). As the phosphorus in the environment increases, the tissue phosphorus concentrations above can also increase the nutritional requirements of the moment (Wilson, 1972; Li et al., 2018).

In this sense, understanding the influence of submerged macrophytes on the available $P$ in water and sediment in semiarid reservoirs is of fundamental importance for water quality management and can contribute to decision making regarding the use of macrophytes as a strategy for the recovery of eutrophic waters.

The present study aimed to evaluate the influence of submerged macrophytes on $\mathrm{P}$ in the water, sediment, and water-sediment interface compartments in a eutrophic reservoir in a semiarid region and to evaluate the relationship between the $\mathrm{P}$ concentration in macrophyte tissue and that available in the different compartments. The following hypotheses were tested: i) there are different $\mathrm{P}$ concentrations inside and outside macrophyte banks in the compartments evaluated; ii) the $\mathrm{P}$ in macrophyte tissue is related to the $\mathrm{P}$ available in the compartments, and this relationship is directly proportional, i.e., the higher the $\mathrm{P}$ concentration in the environment is, the higher its accumulation in macrophytes.

\section{METHODS}

\section{Study site and sampling}

The study was conducted at Epitácio Pessoa Reservoir $\left(07^{\circ} 28^{\prime} 4^{\prime \prime}\right.$ and $07^{\circ} 33^{\prime} 32^{\prime \prime} \mathrm{S} ; 36^{\circ} 08^{\prime} 23^{\prime \prime}$ and $\left.36^{\circ} 16^{\prime} 51^{\prime \prime} \mathrm{W}\right)$, located in the city of Boqueirão, Paraíba state, Brazil (Fig. 1). This reservoir is part of the Paraíba River Basin and is the second largest in the state, with a storage capacity of $411,686,287 \mathrm{~m}^{3}$, area of $2678 \mathrm{ha}$, and altitude of $420 \mathrm{~m}$.

Epitácio Pessoa Reservoir stands out due to its importance in supplying several cities, and thus benefiting a population of over half a million people. However, this reservoir has been affected by anthropogenic activities developed in its drainage basin, such as irrigation, pastures, and subsistence agriculture. Epitácio Pessoa is a meso-eutrophic reservoir with extensive banks of Egeria densa (Planchon) submerged macrophytes in the coastal region along the entire length of the reservoir (Barbosa et al., 2017).

The climate of the region is BSh, characteristic of 
semiarid regions, with an average annual rainfall below $800 \mathrm{~mm}$ (Alvares et al., 2013). The months with higher rainfall generally correspond to February, March, April, and May, but an atypical drought period occurred between 2012 and 2017, with below-average rainfall (below 60 $\mathrm{mm}$ ) (Marengo et al., 2017), which resulted in a drastic reduction in the reservoir's water volume. The lowest volume recorded in Epitácio Pessoa Reservoir in this period was $13,094,571.31 \mathrm{~m}^{3}$ (2.8\% of the maximum reservoir capacity), in April 2017 (AESA, 2017).

Another important event that occurred in the reservoir during the study period was the introduction of water from the São Francisco River starting on April 13, 2017. The São Francisco River is the second largest river in Brazil, and it was diverted to supply reservoirs and rivers located in the semiarid region in the northeast during the dry season (Soares, 2013). The water volume in Epitácio Pessoa Reservoir increased in the months following the water transfer, with a maximum volume of $39,769,906.88 \mathrm{~m}^{3}$ in 2017 (9.66\% of the maximum reservoir capacity).

Sampling was carried out between March 28 and
September 28, 2017, totalling ten collection campaigns, in three reservoir locations (Figs. 1 and 2): at the entrance of the Paraíba River (Zone I); in the intermediate area between the river entrance and the dam (Zone II); and at the dam (Zone III). These zones were selected in our work to contemplate the possible variations in the environmental conditions and the distribution of submerged macrophytes along the reservoir. In each zone, the samples were taken in the coastal and limnetic regions, corresponding to the inside macrophyte bank (IMB) and outside macrophyte bank (OMB) sites, respectively. The details of sampling and analysis of variables are described below and are shown in figure 2. In addition, during the sampling period, water was introduced from the São Francisco River into the reservoir as of the second collection campaign, held on April 24, 2017.

\section{Water transparency, nutrients, and chlorophyll-a}

Water transparency was determined with a Secchi disk. Samples for nutrient and chlorophyll-a analysis were
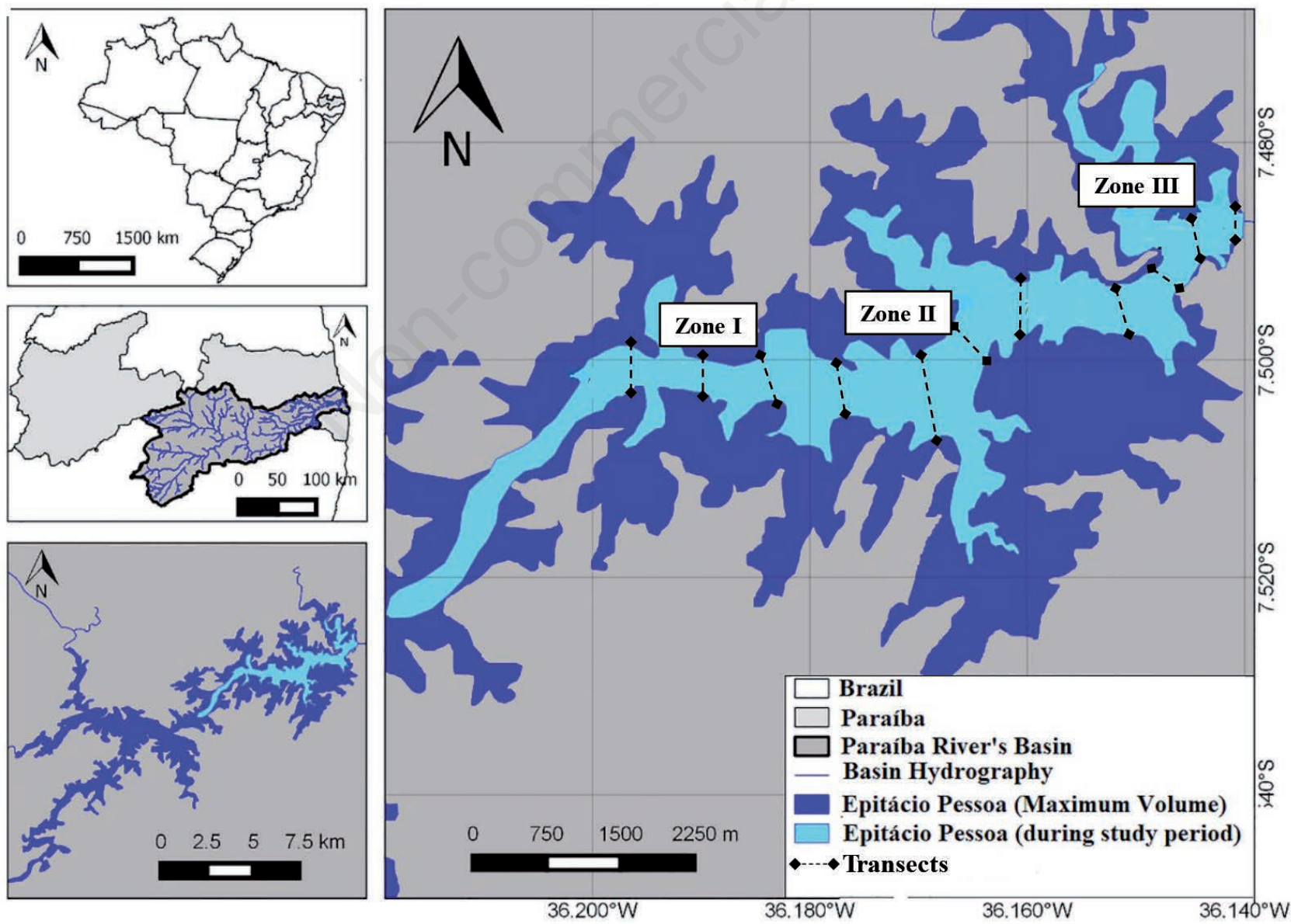

Fig. 1. Location of Epitácio Pessoa Reservoir, Paraíba, Brazil. 
collected in the water column subsurface $(10 \mathrm{~cm})$, stored in plastic bottles, and transported to the laboratory in a cooler with ice. The concentrations of the nutrients ammonia $\left(\mathrm{N}-\mathrm{NH}_{4}\right)$, nitrate $\left(\mathrm{N}-\mathrm{NH}_{3}\right)$, nitrite $\left(\mathrm{N}-\mathrm{NO}_{2}\right)$, dissolved inorganic nitrogen (DIN), soluble reactive P (SRP), and total P (TP) were measured according to the methodology described in the Standard Methods for the Examination of Water and Wastewater (APHA, 2012). DIN was estimated from the sum of the concentrations of $\mathrm{N}-\mathrm{NH}_{4}$, $\mathrm{N}-\mathrm{NH}_{3}$, and $\mathrm{N}-\mathrm{NO}_{2}$.

TP was also measured at the water-sediment interface (at $10 \mathrm{~cm}$ above the sediment) and in the sediment. Sample collection and analysis of the water-sediment interface followed the procedures described to determine TP in water. For sediment analysis, the samples were collected by dredging, dried in an oven to remove moisture, and weighed on an analytical balance. Subsequently, the sediment was macerated and stored in plastic bags at room temperature for analysis, according to the methodology by Tedesco et al. (1995). Chlorophyll-a was extracted with $96 \%$ ethanol, following the method by Jerpersen and Christoffersen (1987), and determined by the spectrophotometric method by Lorezen (1967).

\section{Percent volume infestation}

Macrophyte abundance was estimated by the percent volume infestation (PVI) in 11 transects along the reser- voir distributed in Zones I, II, and III (Fig. 1). In each transect, o PVI was estimated from one margin of the other at regular intervals of $100 \mathrm{~m}$. The PVI was calculated according to the following equation, described by Canfield et al. (1984):

$$
P V I(\%)=\frac{M a c C \times M a c L}{D}
$$

where $\mathrm{MacC}$ is the macrophyte cover (\%), MacL is the macrophyte length $(\mathrm{m})$, and $D$ is the depth (m). Macrophyte cover was visually estimated as the percent cover within $9 \mathrm{~m}^{2}$ plots.

$P$ in the water, sediment, and water-sediment interface compartments and in macrophytes

The collection and analysis of the samples for TP analysis in the water, sediment, and the water-sediment interface followed the procedures described in the previous section.

To determine TP in macrophyte tissue, E. densa shoots $(n=3)$ were collected with pruning shears in an area delimited by a $25 \mathrm{~cm}$ x $25 \mathrm{~cm}$ quadrat and then washed with tap water, dried in an oven at $50^{\circ} \mathrm{C}$, weighed, macerated, and stored in plastic bags at room temperature. The analysis was performed by the acid digestion method $\left(\mathrm{H}_{2} \mathrm{SO}_{4}\right.$ $+\mathrm{H}_{2} \mathrm{O}_{2}$ ) of $0.5 \mathrm{~g}$ macrophyte combined with saturated $\mathrm{MgCl}_{2}$ (Tedesco et al., 1995).

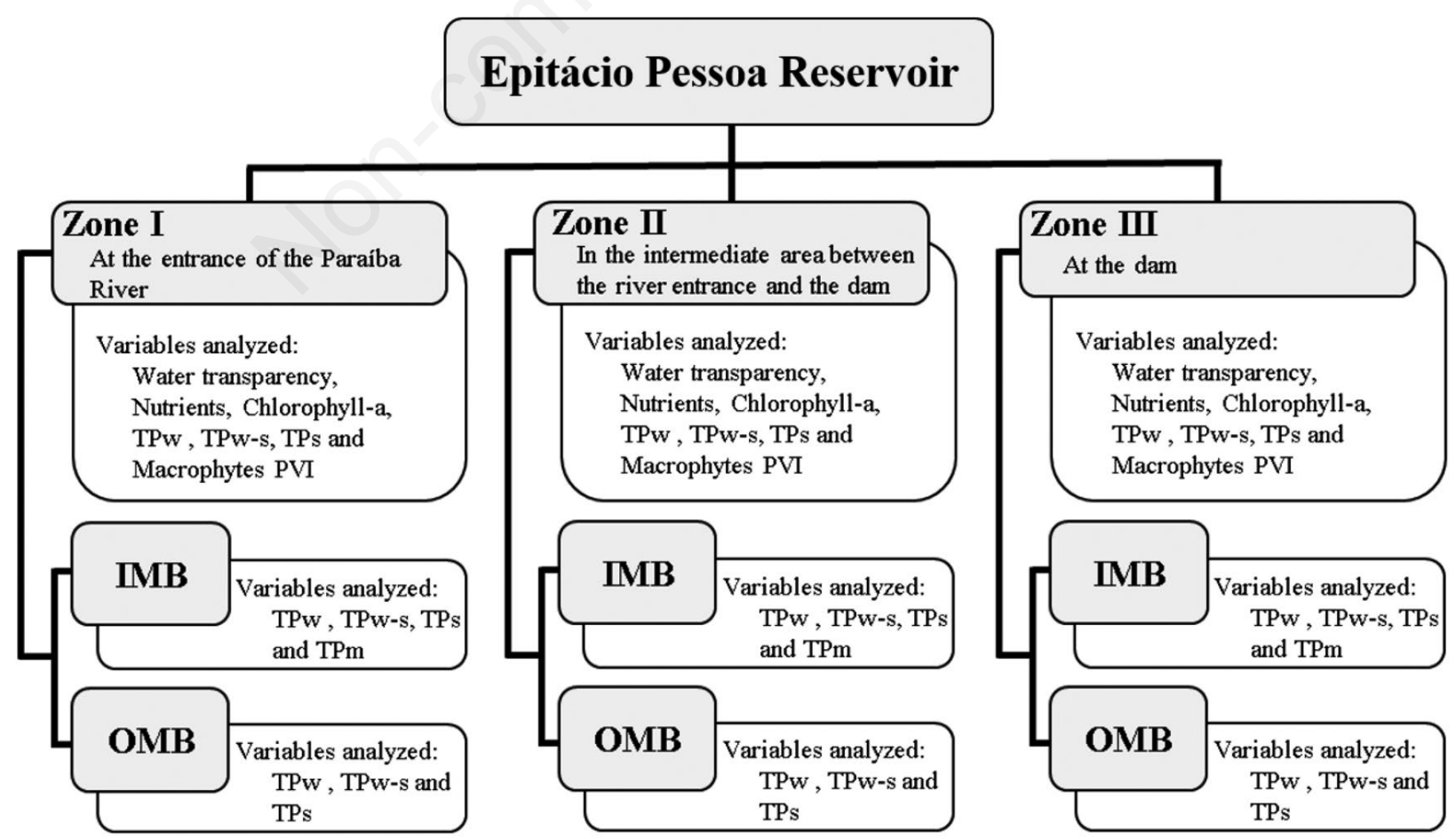

Fig. 2. Study sample design. 


\section{Statistical analysis}

Statistical analyses were performed in the software R, ver. 3.0.1 (R Development Core Team, 2013), considering a significance level of $<0.05$. The Surfer.11 program was used to graph the PVI data considering the zones and sampling campaigns.

To test the significant differences in water transparency, nutrients, and chlorophyll-a concentrations and in the PVI values between Zones I, II, and III, one-factor analysis of variance (one-way ANOVA) and the KruskalWallis test were performed for parametric and nonparametric data, respectively, followed by Tukey's post-hoc test. The normality and homoscedasticity of the data were evaluated through the Kolmogorov-Smirnov and Levene tests, respectively.

The relationships between water transparency, nutrients, and chlorophyll-a were evaluated through principal component analysis (PCA) and the effects of these variables on the PVI were determined through multiple regression analysis (GLM). For the PCA and GLM, the variables were standardized using the standard deviation, and the PCA was performed with the vegan package for $\mathrm{R}$.

To determine significant differences in the TP concentrations inside and outside macrophyte banks in the water, sediment, and water-sediment interface compartments, Student's $t$-test was performed.

To estimate the contribution of $\mathrm{P}$ from the water, sediment, and water-sediment interface compartments to the $\mathrm{P}$ accumulated in macrophyte tissue, a path analysis was performed using the lavaan package for R (Rosseel, 2012). This analysis is based on the relationship between the variables, previously standardized, through a multiple regression model and is described through the equation shown below:

$$
\mathrm{TPm}=\beta_{0}+\beta_{1} * \mathrm{TPw}+\beta_{2} * \mathrm{TPw}-\mathrm{s}+\beta_{3} * \mathrm{TPs}
$$

where TPm is the P concentration in macrophyte tissue; $\beta_{0}$ is the parameter indicating what remains in macrophyte tissue without any contribution from the compartments; $\mathrm{TPw}$ is the $\mathrm{P}$ concentration in the water compartment; $\mathrm{TPw}-\mathrm{s}$ is the $\mathrm{P}$ concentration in the water-sediment interface compartment; TPs is the $\mathrm{P}$ concentration in the sediment compartment; and $\beta_{1}, \beta_{2}$, and $\beta_{3}$ are coefficients that indicate the magnitude and significance of the contributions of the water, water-sediment interface, and sediment compartments, respectively.

The path diagram was constructed to show the direct effects of the $\mathrm{P}$ in the compartments on the $\mathrm{P}$ recorded in macrophyte tissue as well as the correlations between the compartments. The semPlot package for $\mathrm{R}$ was used to construct the diagram (Epskam, 2015), using the "tree" layout.

\section{RESULTS}

\section{Water transparency, nutrients, and chlorophyll-a}

Epitácio Pessoa Reservoir showed significant differences in water transparency and nutrient and chlorophyll-a concentrations between the zones (Tab. 1; Figs. 3 and 4).

Zones I and II showed significantly lower water transparency and higher concentrations of SRP, N-NO $\mathrm{N}_{2}, \mathrm{~N}-$ $\mathrm{NH}_{3}, \mathrm{~N}-\mathrm{NH}_{4}$, DIN, and chlorophyll-a (Tab. 1). The TP concentrations in water, in the water-sediment interface, and in sediment were also significantly higher in Zones I and II (Tab. 1).

The lowest transparency and highest nutrient concentrations were recorded starting on the second collection campaign (April 24). Starting on the $6^{\text {th }}$ or $7^{\text {th }}$ collection

Tab. 1. Water transparency, concentrations of nutrients and chlorophyll-a in Zones I, II, and III of Epitácio Pessoa Reservoir, Paraíba, Brazil, between March 28 and September 28, 2017.

\begin{tabular}{|c|c|c|c|c|}
\hline \multirow[t]{2}{*}{ Variables } & \multicolumn{3}{|c|}{ Sampling points } & \multirow[t]{2}{*}{$F$ and $P$ values } \\
\hline & Zone I & Zone II & Zone III & \\
\hline Water transparency $(\mathrm{cm})$ & $0.68 \pm 0.12^{\mathrm{a}}$ & $1.04 \pm 0.17^{\mathrm{a}}$ & $1.42 \pm 0.05^{\mathrm{b}}$ & $4.27 ; 0.0243$ \\
\hline $\operatorname{SRP}\left(\mu \mathrm{g} \mathrm{L}^{-1}\right)$ & $101 \pm 12.21^{\mathrm{a}}$ & $108.85 \pm 16.27^{\mathrm{a}}$ & $54.25 \pm 7.68^{b}$ & $8.72 ; 0.001$ \\
\hline $\mathrm{TPw}\left(\mu \mathrm{g} \mathrm{L}^{-1}\right)$ & $435.43 \pm 87.71^{\mathrm{a}}$ & $236.60 \pm 28.44^{\mathrm{a}}$ & $69.55 \pm 4.57^{b}$ & $6.12 ;<0.001$ \\
\hline TPw-s $\left(\mu \mathrm{g} \mathrm{L}^{-1}\right)$ & $2,323.65 \pm 304.14^{\mathrm{a}}$ & $1,094.45 \pm 131.44^{\mathrm{a}}$ & $183.70 \pm 9.56^{\mathrm{b}}$ & $7.23 ;<0.001$ \\
\hline TPs $\left(\mathrm{mg} \mathrm{g}^{-1}\right)$ & $0,71 \pm 0.03^{\mathrm{a}}$ & $0.44 \pm 0.06^{\mathrm{a}}$ & $0.45 \pm 0.01^{\mathrm{b}}$ & $11.56 ;<0.001$ \\
\hline Nitrite $\left(\mu \mathrm{g} \mathrm{L}^{-1}\right)$ & $56.64 \pm 24.54^{\mathrm{a}}$ & $72.31 \pm 29.09^{\mathrm{a}}$ & $24.93 \pm 6.52^{b}$ & $6: 45 ; 0.001$ \\
\hline Nitrate $\left(\mu \mathrm{g} \mathrm{L}^{-1}\right)$ & $119.72 \pm 28.79^{\mathrm{a}}$ & $236.05 \pm 63.71^{\mathrm{a}}$ & $58.93 \pm 12.95^{\mathrm{b}}$ & $8.40 ; 0.001$ \\
\hline Ammonia $\left(\mu \mathrm{g} \mathrm{L}^{-1}\right)$ & $108.80 \pm 25.47^{\mathrm{a}}$ & $65.71 \pm 9.69^{\mathrm{a}}$ & $41.52 \pm 5.60^{\mathrm{b}}$ & $6.10 ; 0.02$ \\
\hline $\mathrm{DIN}\left(\mu \mathrm{g} \mathrm{L}^{-1}\right)$ & $285.16 \pm 71.45^{\mathrm{a}}$ & $374.07 \pm 93.31^{\mathrm{a}}$ & $125.38 \pm 19.54^{b}$ & $6.46 ; 0.002$ \\
\hline Chlorophyll-a $\left(\mu \mathrm{g} \mathrm{L}^{-1}\right)$ & $18.08 \pm 0.85^{\mathrm{a}}$ & $15.04 \pm 1.35^{\mathrm{a}}$ & $12.71 \pm 0.72^{b}$ & $3.04 ; 0.002$ \\
\hline
\end{tabular}



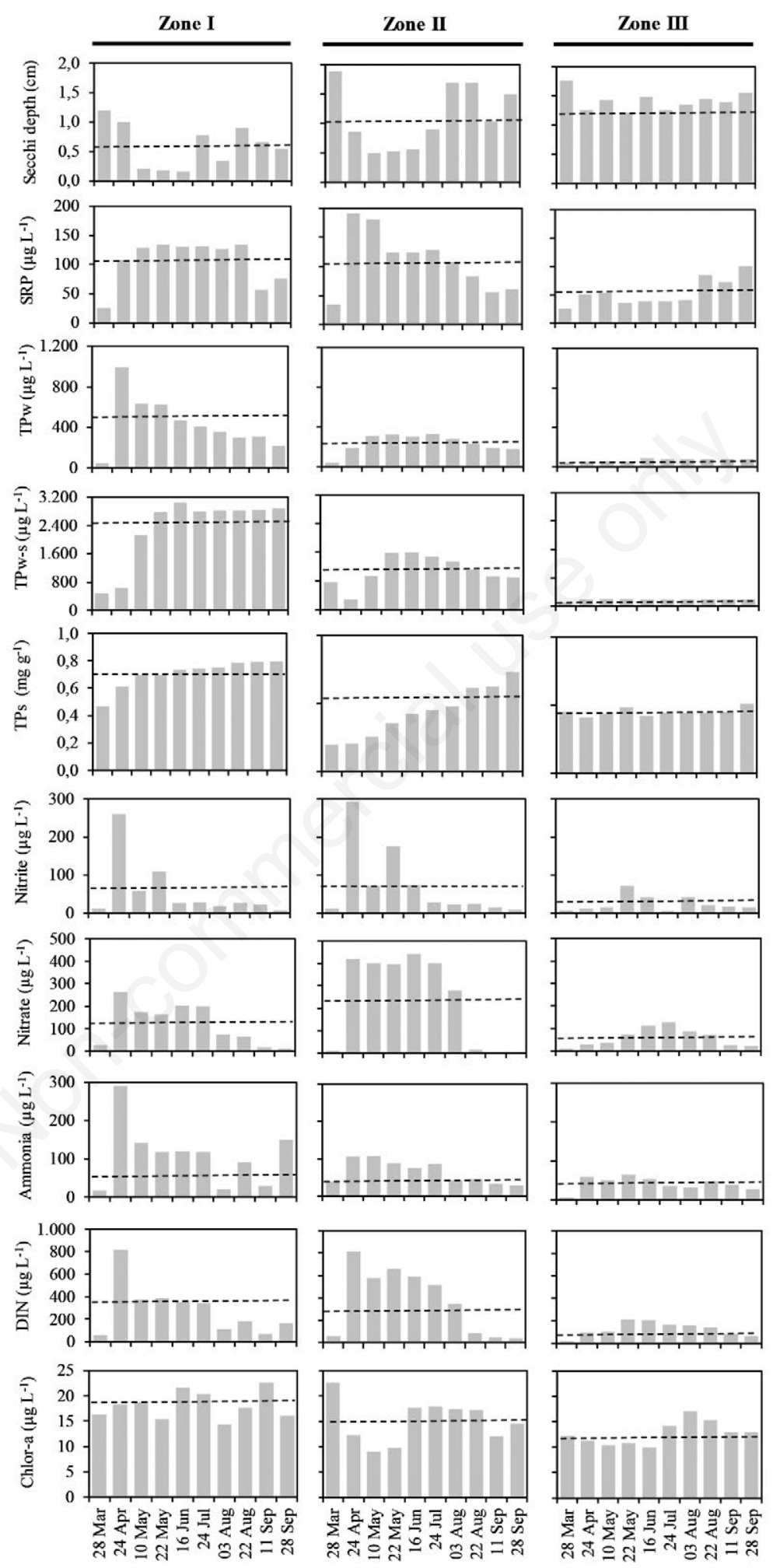

Fig. 3. Water transparency, concentrations of nutrients and chlorophyll-a in Zones I, II, and III of Epitácio Pessoa Reservoir, Paraíba, Brazil, between March 28 and September 28, 2017. The dashed line represents the arithmetic mean. SRP, soluble reactive phosphorus; $\mathrm{TPw}$, total phosphorus in water; TPw-s, total phosphorus in the water-sediment interface; TPs, total phosphorus in the sediment; DIN, dissolved inorganic nitrogen; Chlor-a, chlorophyll-a. 
campaign, we observed renewed transparency and reduced nutrient concentrations in Zones I and II, with values not significantly different from those recorded on April $24(\mathrm{P}<0.05)$.

In Zone III, although nutrient concentrations were lower than those observed in Zones I and II, the same pattern of increased nutrient concentrations was observed starting on April 24 followed by a gradual reduction over the sampling period (Fig. 3).

The PCA explained $73.08 \%$ of the variability in the data, with axes 1 and 2 explaining 55.99 and $17.09 \%$, respectively. In the ordination, the sampling zones formed distinct groups, with Zone I related to the highest concentrations of SRP, TP (water, water-sediment interface, and

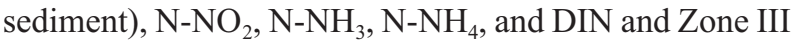
with the highest water transparency. Zone II had an intermediate position between Zones I and III (Fig. 4).

The sampling units of the $1^{\text {st }}, 7^{\text {th }}, 8^{\text {th }}, 9^{\text {th }}$, and $10^{\text {th }}$ collection days were clustered, being related to the conditions of greater water transparency and lower SRP, TP, $\mathrm{N}^{-\mathrm{NO}_{2}}$, $\mathrm{N}-\mathrm{NH}_{3}, \mathrm{~N}-\mathrm{NH}_{4}$, and DIN concentrations.

\section{PVI of macrophytes}

The PVI showed significant differences among zones $(\mathrm{F}=7.85 ; \mathrm{P}=0.002)$, with values ranging from 33.67 to $91.10 \%$ in Zone I, 42.01 to $72.86 \%$ in Zone II, and 40.26 to $50.71 \%$ in Zone III (Fig. 5).

Zones I and II showed a similar PVI pattern over the sampling days. The PVI values in these zones decreased gradually from April 24 to August 3 and increased again after this period. In Zone I, the PVI was $91.10 \%$ on March 28 , totalling $33.67 \%$ on June 16 , and $91.10 \%$ on September 28 , whereas in Zone II the PVI was $72.85 \%$ on March 28 , decreasing to $42.01 \%$ on June 16 , and $68.93 \%$ on September 28 .

The multiple regression analysis was significant $(\mathrm{F}=7.04 ; \mathrm{P}<0.001)$ and showed that water transparency (Secchi), N-NH ${ }_{3}$, and TP at the water-sediment interface (TPw-s) were directly related to PVI, whereas chlorophyll-a (Chlor-a) showed an inverse relationship, as described in the following equation:

$$
\begin{gathered}
\mathrm{Y}=-0.02+0.72 * \text { Secchi }+0.74 * \mathrm{~N}-\mathrm{NH}_{3}+ \\
\quad 0.57 * \mathrm{TPw}-\mathrm{s}-0.45 * \text { Chlor-a }
\end{gathered}
$$

$P$ in the water, sediment, and water-sediment interface compartments and inside and outside macrophyte banks

The influence of macrophytes on the TP concentration in the water, sediment, and water-sediment interface varied among zones (Fig. 6).

In the water, the TP concentration differed significantly inside and outside the macrophyte banks in Zone II, with a lower concentration inside the banks $\left(166.13 \mu \mathrm{g} \mathrm{L} \mathrm{L}^{-1} \pm 51.26\right.$ $\left.\mu \mathrm{g} \mathrm{L}^{-1}\right)$. In the water-sediment interface, Zone I showed a higher TP concentration in the banks $\left(3,130 \mu \mathrm{g} \mathrm{L}^{-1} \pm 10.59\right.$ $\mu \mathrm{g} \mathrm{L}^{-1}$ ), whereas in Zone III, the TP concentration was higher outside the banks $\left(396.11 \pm 961.6 \mu \mathrm{g} \mathrm{L}^{-1}\right)$. The sediment showed a higher TP concentration inside the macrophyte banks in Zone I $\left(0.98 \mathrm{mg} \mathrm{g}^{-1} \pm 0.10 \mathrm{mg} \mathrm{g}^{-1}\right)$ and outside the banks in Zones II and III $\left(0.63 \mathrm{mg} \mathrm{g}^{-1} \pm 0.03 \mathrm{mg}\right.$ $\mathrm{g}^{-1}$ and $1.04 \mathrm{mg} \mathrm{g}^{-1} \pm 0.19 \mathrm{mg} \mathrm{g}^{-1}$, respectively).

\section{$P$ in macrophyte tissue and relationship to $P$ in the water, sediment, and water-sediment interface compartments}

The TP concentration in macrophyte tissue differed among the zones $(\mathrm{F}=11.9 ; \mathrm{p}=0.01)$. The macrophytes located in Zones I and II showed the highest P concentrations, consisting of $4.08 \mathrm{mg} \mathrm{g}^{-1} \pm 0.75 \mathrm{mg} \mathrm{g}^{-1}$ and $3.44 \mathrm{mg}$ $\mathrm{g}^{-1} \pm 0.29 \mathrm{mg} \mathrm{g}^{-1}$, respectively (Fig. 7).

Path analysis showed that the water-sediment interface was the compartment that significantly influenced the $\mathrm{P}$ in macrophyte tissue, and this relationship was directly proportional (Fig. 8). A direct and significant correlation in $\mathrm{P}$ concentrations between the compartments was also observed.

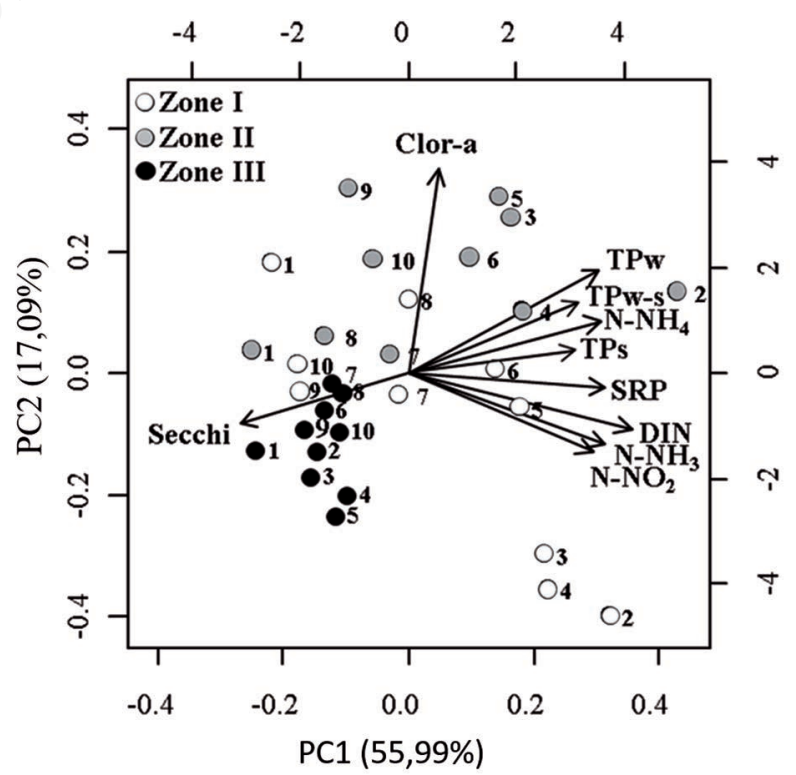

Fig. 4. Principal component analysis (PCA) with variables in sampling zones. Secchi, water transparency; $\mathrm{N}_{-} \mathrm{NH}_{3}$, nitrate; N$\mathrm{NO}_{2}$, itrite; $\mathrm{N}-\mathrm{NH}_{4}$, ammonia; DIN, dissolved inorganic nitrogen; SRP, soluble reactive phosphorus; TPw, total phosphorus in water; TPw-s, total phosphorus in the water-sediment interface; TPs, total phosphorus in the sediment; Chlor-a, chlorophyll-a. Sampling date: 1, March 28; 2, April 24; 3, May 10; 4, May 22; 5, June 16; 6, July 24; 7, August 03; 8, August 22; , October 11; 9, October 28. 

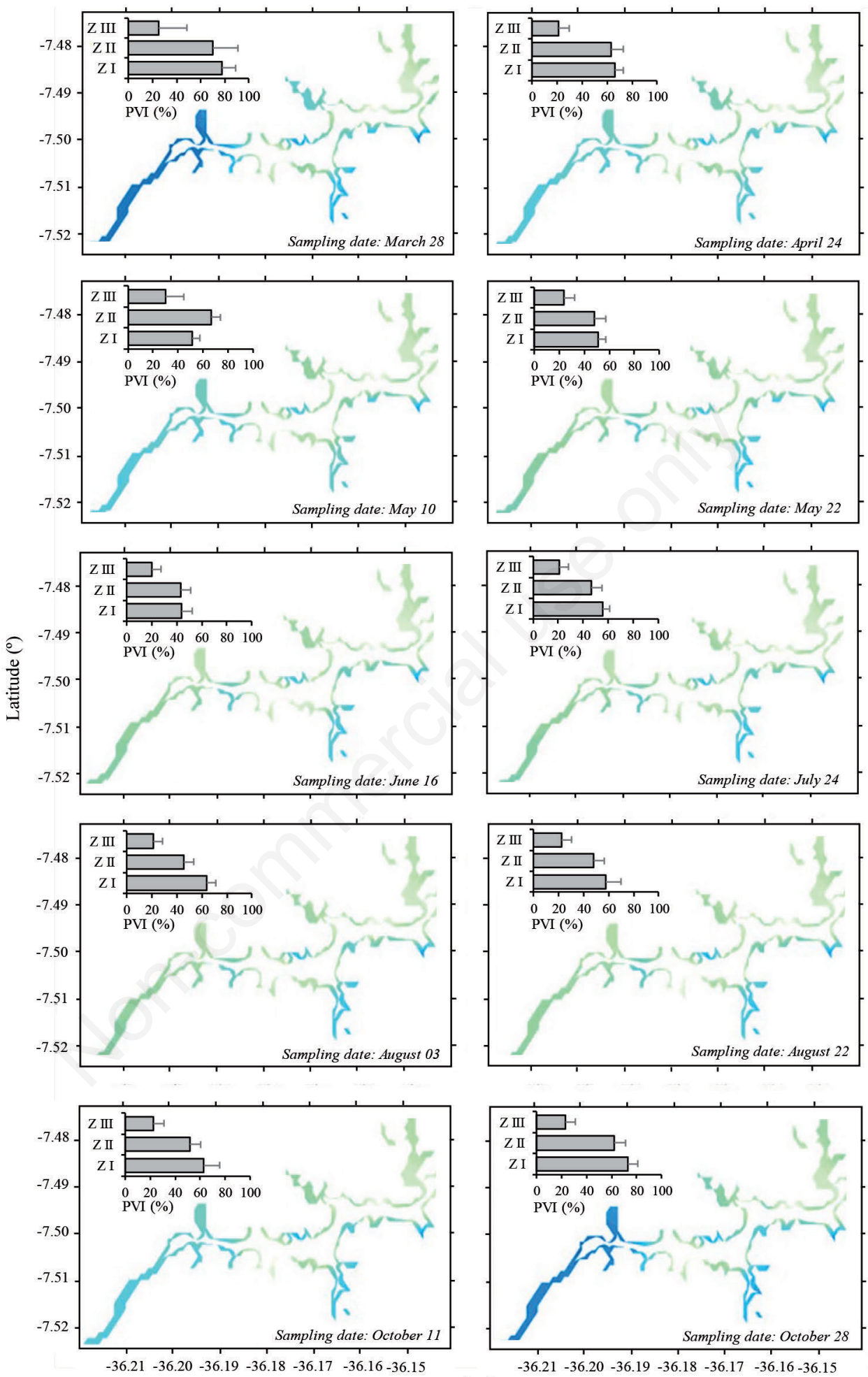

Longitude ( ${ }^{\circ}$ )

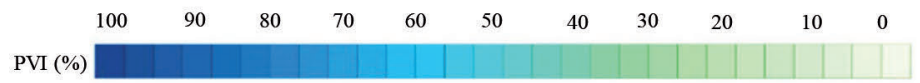

Fig. 5. Percent volume infestation (PVI) of macrophytes in Epitácio Pessoa Reservoir, Paraíba, Brazil, between March 23 and September 28, 2017. The columns are the arithmetic mean and standard error of the PVI per sampled zone. 


\section{DISCUSSION}

In the present study, we tested the hypotheses that submerged macrophytes have a significant influence on the available $P$ in a reservoir in a semiarid region and that the
$\mathrm{P}$ accumulated in macrophyte tissue is directly proportional to that available in the environment.

We observed a difference in $\mathrm{P}$ concentration inside and outside macrophyte banks, and this difference was influenced by the variations in abundance of these plants. In
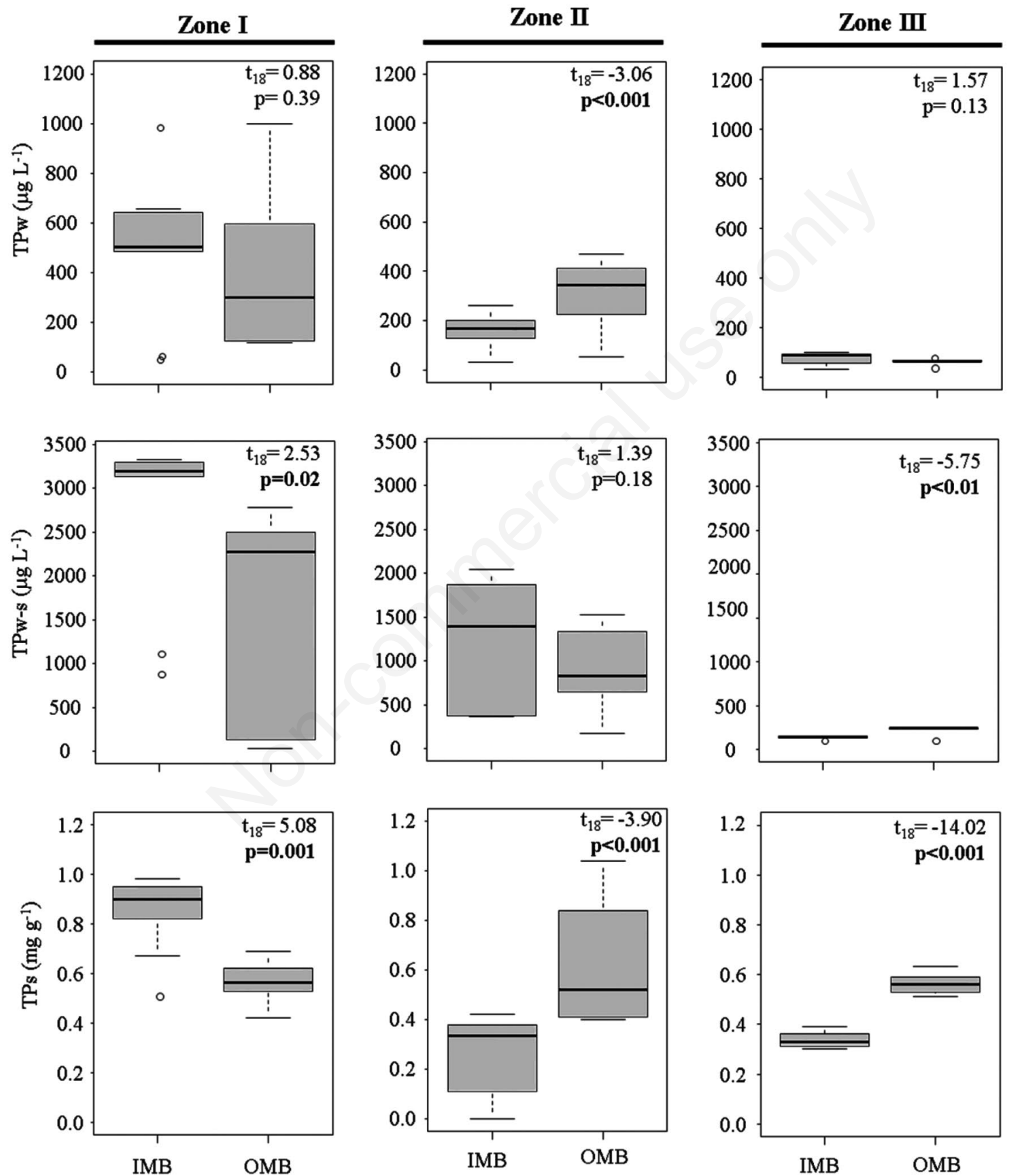

Fig. 6. Total phosphorus concentrations in the water (TPw), water-sediment interface (TPw-s), and sediment (TPs) compartments of Zones I, II, and III of Epitácio Pessoa Reservoir, Paraíba, Brazil. IMB, inside macrophyte banks; OMB, outside macrophyte banks. The lower and upper extremities of the box plot are the first and the third quartiles, respectively, and the centre line represents the median. The white balls represent outliers. 
the zone near the river entrance, where the macrophytes formed extensive vegetation banks and where decomposition was more intense, $\mathrm{P}$ was released at the water-sediment interface and sediment compartments as evidenced by the abrupt reductions in PVI. In turn, in the dam zone,

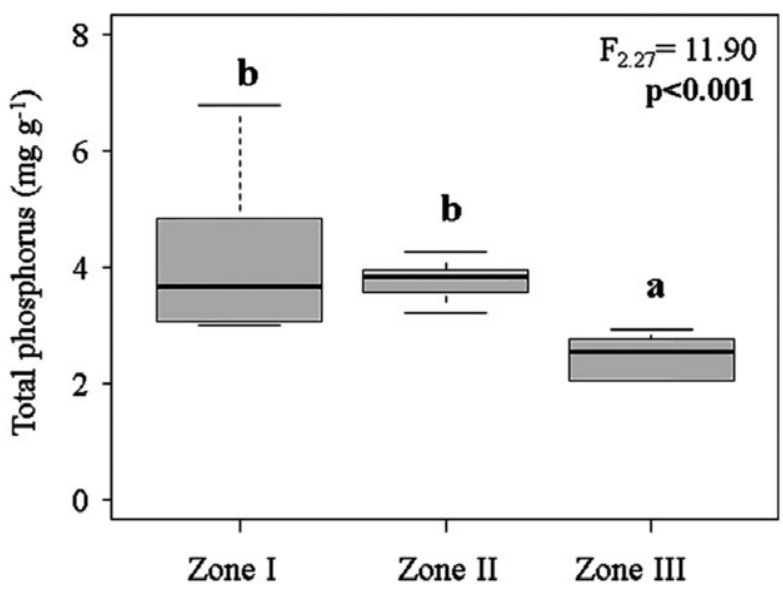

Fig. 7. TP concentration in macrophyte tissue in Zones I, II, and III of Epitácio Pessoa Reservoir, Paraíba, Brazil.

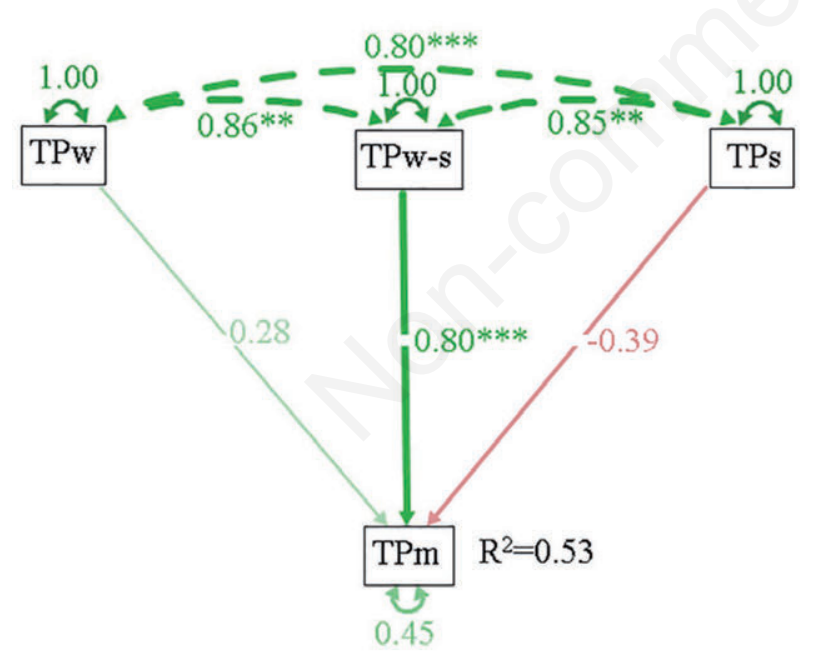

Fig. 8. Path diagram testing the effects of total phosphorus in the water (TPw), sediment (TPs), and water-sediment interface (TPw-s) compartments on the phosphorus $(\mathrm{P})$ concentration in macrophyte tissue (TPm). The direct effects of the P in the compartments on that found in the macrophytes are indicated by solid arrows, and dashed arrows show the correlations between the $\mathrm{P}$ concentrations in the compartments. The green and red arrows represent positive and negative effects, respectively. The numbers next to the lines are the path coefficients with the level of significance. The $\mathrm{R}^{2}$ value above the TP in the macrophyte tissue box represents the total variation explained by the model. $* \mathrm{P}<0.05 ; * * \mathrm{P}<0.01 ; * * * \mathrm{P}<0.0001$. where the macrophyte banks were more stable and without large variations in abundance, $\mathrm{P}$ was removed from the compartments.

A relationship between $\mathrm{P}$ in macrophyte tissue and that available in the environment was observed, particularly at the water-sediment interface, indicating that this compartment was the main P source for these plants. This result contrasts with other studies that show that submerged macrophytes primarily use P from sediment (Rooney et al., 2004; Horppila and Nurminen, 2003; Yu et al., 2018).

The transfer of water from the São Francisco River was an important modifying factor of the physical and chemical characteristics and macrophyte abundance in Epitácio Pessoa Reservoir. This reservoir is historically characterized as meso-eutrophic, containing clear water and extensive banks of E. densa (Araújo-Junior, 2009), but the introduction of water from the São Francisco River has caused a reduction in macrophyte abundance.

Water transfer from a river increases the water current velocity in receiving systems, with a consequent increase in sediment resuspension, which causes a reduction in water transparency (Verhofstad et al., 2017). A reduction in macrophyte abundance occurs because these organisms depend directly on light for growth (Lamers et al., 2012; Verhofstad et al., 2017), and this relationship was observed in our study, as the lowest PVI values were recorded under lower transparency conditions. However, the water flow caused by water transfer can also adversely affect macrophyte growth, causing mechanical damage and detachment of roots or stems from sediment (Heidbüchel and Hussner, 2019). In addition, because the resuspended sediment is formed largely by smaller particles (fine sediment), this resuspension hinders root fixation in the remaining coarse sediment and may cause a reduced photosynthetic rate, since the sedimentation of resuspended fine particles results in shading photosynthetic surfaces and in burying plants (Madsen et al., 2001).

The zone where the river enters the reservoir was the area most affected by the water transfer. The macrophyte decomposition in this zone resulted in the highest $\mathrm{P}$ concentration in the water-sediment interface and sediment compartments, which demonstrates the importance of macrophytes in the fertilization of water bodies and, consequently, in the eutrophication process. Submerged macrophytes release the available $\mathrm{P}$ in their tissue to the external environment through decomposition (Barbosa et al., 2017), and studies show that the percent released reaches $32.30 \%$ in 30 days (Wang et al., 2018). Several weeks after the water transfer, we observed increased water transparency and reduced nutrient concentrations, which may be explained by a possible dilution and sedimentation effect of the suspended particles, as expected after a prolonged period of transferred water flow (Zeng et al., 2015). These changes resulted in resumed $E$. densa 
growth, with observed PVI values that were not different from those recorded in the period prior to water transfer. In the Delmiro Gouveia and Apolônio Sales reservoirs, located in the Paulo Afonso Hydroelectric Complex (Bahia, Brazil), research showed that this species was able to completely reoccupy empty spaces in the reservoirs within three weeks (Oliveira et al., 2005).

$E$. densa recolonization does not usually occur from seeds, but rather through stem fragments that produce adventitious roots and attach to substrate (Kuntz et al., 2014). These fragments have low buoyancy and, therefore, have high odds of anchorage success in the sediment for growth (Heidbüchel and Hussner, 2019).

Macrophyte P removal in the dammed and transition zones occurred for growth maintenance, since the abundance of these plants remained relatively constant in these zones. Nutrient absorption by submerged aquatic plants involves root and leaf mechanisms, and translocation is performed from one tissue to another (Angelstein and Schubert, 2008). Studies have shown that sediment is the main P source for macrophytes (Horppila and Nurminen, 2003 ), since the $P$ found in water is usually temporary, as rapid assimilation by algae or loss by sedimentation can occur (Human et al., 2015).

In our study, we observed $\mathrm{P}$ removal from the sediment by macrophytes, but the water-sediment interface was the main P source. This compartment generally has anaerobic conditions due to sediments rich in organic matter, high sediment oxygen demand, and low oxidation potential, which results in trapping $\mathrm{P}$ in the sediment. However, the presence of aerenchyma provides an oxygen exchange layer for the roots and rhizosphere and, consequently, P releases to the plant (Hupfer and Dollan, 2003; Pi et al., 2011). In addition, the generation of sharp redox gradients in iron-rich sediment leads to formation of iron crusts around roots. These crusts are capable of binding to substantial portions of $\mathrm{P}$ and may serve as a temporary $P$ reservoir for a plant that is even more efficient than plant tissue (Hupfer and Dollan, 2003; Pi et al., 2011).

The relationship between the $\mathrm{P}$ present in macrophyte tissue and that available in the compartments corroborates the findings of other studies, which show that these plants store higher $\mathrm{P}$ amounts in sediment and water rich in this nutrient (Li et al., 2018). This circumstance is believed to occur when nutrient concentrations in water are higher than required by macrophytes, which cause them to absorb excess nutrients and store them in tissue through a process known as "luxury absorption" (Baldy et al., 2015; Muller, Thiebaut, 2015; Xing et al., 2016; Lu et al., 2017). Therefore, the P content of submerged macrophyte tissue reflects the nutritional status of the aquatic environment in which plants are present, and macrophytes can thus serve as quality indicators of an aquatic environment $(\mathrm{Li}$ et al., 2018). This finding is of great importance for un- derstanding and managing aquatic systems, since the increase in this nutrient concentration in water, and even in sediment, is one of the important reasons for algal blooms (Tong et al., 2017), which in turn are directly related to submerged macrophytes, as shown in our study.

Thus, the P dynamic involving submerged macrophytes is a two-way street, as macrophytes remove or release this nutrient. $\mathrm{P}$ monitoring is necessary for understanding $\mathrm{P}$ bioavailability in an aquatic system and for establishing less eutrophic conditions.

\section{CONCLUSIONS}

Our results showed that submerged macrophytes alter $P$ availability, mainly in the water-sediment interface and sediment compartments in a reservoir in a semiarid region. $\mathrm{P}$ is released by macrophytes at sites where they form extensive banks and undergo intense decomposition, whereas $\mathrm{P}$ is removed where these plants are more stable, without great abundance variations.

The factors that alter the physical and chemical characteristics of reservoirs, such as river water transfer, also have significant effects on the abundance of submerged macrophytes and on P removal and release by these organisms.

The water-sediment interface is the main P source for submerged macrophytes, and there is a direct relationship between the $\mathrm{P}$ in their tissue and that available in the environment, functioning as an indicator of the trophic state of a reservoir.

\section{ACKNOWLEDGMENTS}

The authors would like to thank the FAPESQ (Foundation for Research Support of the State of Paraíba) and CNPq (National Council for Scientific and Technological Development), (process 88887.142333/2017-00) for the financing of this study; the PPGCTA-UEPB (Environmental Science and Technology Pos-Graduation Program of State University of Paraíba) and the Ecology Aquatic Laboratory team-UEPB for the support during the research time.

\section{REFERENCES}

Alvares CA, Stape JL, Sentelhas PC, de Moraes Gonçalves JL, Sparovek G, 2013. Köppen's climate classification map for Brazil. Meteo. Z. 22: 711-728.

Angelstein S, Schubert H, 2008. Elodea nuttallii: uptake, translocation and release of phosphorus. Aquat. Bot. 3:208216.

APHA, 2012. Standard methods for the examination of 457 water and wastewater. Washington DC: APHA - AWWA WPCF. 19.

Araújo-Júnior RJ, 2009. [Evolução temporal dos níveis tróficos 
do açude Epitácio Pessoa, semi-árido Paraibano].[PhD Thesis in Portuguese]. Universidade Estadual da Paraíba.

Baldy V, Thiebaut G, Fernandez C, Sagova-Mareckova M, Korboulewsky N, Monnier Y, Tremolieres M, 2015. Experimental assessment of the water quality influence on the phosphorus uptake of an invasive aquatic plant: Biological responses throughout its phenological stage. PLoS One 10:1-17.

Barbosa JEL, Medeiros ESF, Brasil J, Cordeiro RS, Crispim MCB, Silva GHG, 2012. Aquatic systems in semi-arid Brazil: limnology and management. Acta Limnol. Bras. 24:103-118.

Barbosa VV, Barbosa JEL, Hepp LU, Santino MBC, Nery JF, 2017. Anaerobic decomposition of submerged macrophytes in semiarid aquatic systems under different trophic states, Paraíba State, Brazil. Afr. J. Biotechnol. 16:2258-2266.

Barko JW, Smat RM, 1980. Mobilization of sediment phosphorus by submersed freshwater macrophytes. Freshwater Biol. 10:229-238.

Bianchini Junior, I, Cunha-Santino, MB, Ribeiro, JU, Penteado, DGB, 2014. Implication of anaerobic and aerobic decomposition of Eichhornia azurea (Sw.) Kunth. on the carbon cycling in a subtropical reservoir. Braz. J. Biol. 74:100-110.

Canfield DF, Shireman VJ, Colle DE, Halle, WT, Watkins II CR, Maceina MJ, 1984. Prediction of chlorophyll a concentrations in Florida lakes: importance of aquatic macrophytes. Can. J. Fish. Aquat. Sci. 41:497-501.

Carpenter SR, Caraco NF, Correll DL, Howarth RW, Sharpley AN, Smith VH, 1998. Nonpoint pollution of surface waters with phosphorus and nitrogen. Ecol. Appl. 8:559.

Carpenter SR, Lodge DM, 1986. Effects of submersed macrophytes on ecosystem processes. Aquat. Bot. 26: 341370.

Carignan R, Kalff J, 1980. Phosphorus sources for aquatic weeds: water or sediments? Science 207:987-989.

Chamier J, Schachtschneider K, Le Maitre DC, Ashton PJ, van Wilgen BW, 2012. Impacts of invasive alien plants on water quality, with particular emphasis on South Africa. Water SA 38:345-356.

Correll DL, 1998. The role of phosphorus in the eutrophication of receiving waters: A review. J. Environ. Qual. 27: 261.

Epskamp S, 2015. semPlot: Unified visualizations of structural equation models. Structural equation models. Available at: http://www.sachaepsamp.com/files/semPlot.pdf

Feijoó C, García, ME, Momo F, Toja J, 2002. Nutrient absorption by the submerged macrophyte Egeria densa Planch.: Effect of ammonium and phosphorus availability in the water column on growth and nutrient uptake. Lirnnetica 21:103-104.

Finkler Ferreira T, Crossetti LO, Motta Marques DML, Cardoso L, Fragoso CR, van Nes EH, 2018. The structuring role of submerged macrophytes in a large subtropical shallow lake: Clear effects on water chemistry and phytoplankton structure community along a vegetated-pelagic gradient. Limnologica 69:142-154.

Gabrielson JO, Perkins MA, Welch EB, 1984. The uptake, translocation and release of phosphorus by Elodea densa. Hydrobiologia 111:43-48.

Heidbuchel P, Hussner A, 2019. Fragment type and water depth determine the regeneration and colonization success of submerged aquatic macrophytes. Aquat. Sci. 81:1-6.

Hilborn E, Beasley V, 2015. One health and cyanobacteria in freshwater systems: Animal illnesses and deaths are sentinel events for human health risks. Toxins 7:1374-1395.

Holmroos H, Horppila J, Niemistö J, Nurminen L, Hietanen S, 2014. Dynamics of dissolved nutrients among different macrophyte stands in a shallow lake. Limnology 16:31-39.

Horppila J, Nurminen L, 2003. Effects of submerged macrophytes on sediment resuspension and internal phosphorus loading in Lake Hiidenvesi (southern Finland). Water Res. 37: 468-4474.

Huang J, Xu C, Ridoutt BG, Wang X, Ren P, 2017. Nitrogen and phosphorus losses and eutrophication potential associated with fertilizer application to cropland in China. J. Clean Prod. 159:171-179.

Huisman J, Codd GA, Paerl HW, Ibelings BW, Verspagen JMH, Visser PM, 2018. Cyanobacterial blooms. Nat. Rev. Microbiol. 16:471-483.

Human LRD, Snow GC, Adams JB, Bate GC, Yang S-C, 2015. The role of submerged macrophytes and macroalgae in nutrient cycling: A budget approach. Estuar. Coast. Shelf Sci. 154:169-178.

Hupfer M, Dollan A, 2003. Immobilisation of phosphorus by iron-coated roots of submerged macrophytes. Hydrobiologia 506-509:635-640.

Jespersen AM, Christoffersen K, 1987. Measurements of chlorophyll-a from phytoplankton using ethanol as extraction solvent. Arch. Hydrobiol. 109:445-454.

Kuntz K, Heidbüchel P, Hussner A, 2014. Effects of water nutrients on regeneration capacity of submerged aquatic plant fragments. Ann. Limnol. - Int. J. Limnol. 50:155-162.

Lamers L, Schep S, Geurts J, Smolders A, 2012. [Erfenis fosfaatrijk verleden: Helder water met woekerende waterplanten].[Article in Dutch]. $\mathrm{H}_{2} \mathrm{O}$ 13:29-31.

Levi PS, Riis T, Alnøe AB, Peipoch M, Mætszke K, Pedersen $\mathrm{CB}, 2015$. Macrophyte complexity controls nutrient uptake in lowland streams. Ecosystems 18:914-931.

Li J, Yang X, Wang Z, Shan Y, Zheng Z, 2015. Comparison of four aquatic plant treatment systems for nutrient removal from eutrophied water. Bioresour. Technol. 179:1-7.

Li W, Li Y, Zhong J, Fu H, Tu J, Fan H, 2018. Submerged macrophytes exhibit different phosphorus stoichiometric homeostasis. Front. Plant Sci. 9:1-9.

Lone PA, Bhaerdwaj AK, Shah KW, 2014. Macrophytes as powerful natural tools for water quality improvement. Res. J. Bot. 9:24-30.

Lorenzen CJ, 1967. Determination of chlorophyll and phaeopigments: spectrophotometric equations. Limnol. Oceanogr. 12:343-346.

Lu J, Bunn SE, Burford MA, 2018. Nutrient release and uptake by littoral macrophytes during water level fluctuations. Sci.Total Environ. 622-623:29-40.

Lu J, Faggotter SJ, Bunn SE, Burford MA, 2017. Macrophyte beds in a subtropical reservoir shifted from a nutrient sink to a source after drying then rewetting. Freshwater Biol. 62:854-867.

Lürling M, Mackay E, Reitzel K, Spears BM, 2016. A critical perspective on geo-engineering for eutrophication management in lakes. Water Res. 97:1-10. 
Madsen JD, Chambers PA, James WF, Koch EW, 2001. The interaction between water movement, sediment dynamics and submersed macrophytes. Hydrobiologia 444:71-84.

Marengo JA, Alves LM, Alvala RC, Cunha AP, Brito S, Moraes OLL, 2017. Climatic characteristics of the 2010-2016 drought in the semiarid Northeast Brazil region. Ann. Acad. Bras. Cienc. 90:1973-1985.

Marengo, JA, Jones, R, Alves, LM, Valverde, MC, 2009. Future change of temperature and precipitation extremes in South America as derived from the PRECIS regional climate modeling system. Int. J. Climatol. 29:2241-2255.

Moore MT, Locke MA, Kröger R, 2016. Using aquatic vegetation to remediate nitrate, ammonium, and soluble reactive phosphorus in simulated runoff. Chemosphere 54:149-160.

Mosley LM, 2015. Drought impacts on the water quality of freshwater systems; review and integration. Earth Sci. Rev. 140:203-214.

Nascimento PRF, Pereira SMB, Sampaio EVSB, 2008. [Biomassa de Egeria densa nos reservatórios da hidroelétrica de Paulo Afonso-Bahia].[Article in Portuguese]. Planta Daninha 26:481-486.

Oliveira NMB, Sampaio EVSB, Pereira SMB, Moura Junior $\mathrm{AM}, 2005$. [Capacidade de regeneração de Egeria densa nos reservatórios de Paulo Afonso, BA].[Article in Portuguese]. Planta Daninha 23:263-369.

Pi N, Tam NF, Wong MH, 2011. Formation of iron plaque on mangrove roots receiving wastewater and its role in immobilization of wastewater-borne pollutants. Mar. Pollut. Bull. 63:402-411.

Rocha Junior CAN, Costa MRA, Menezes RF, Attayde JL, Becker V, 2018. Water volume reduction increases eutrophication risk in tropical semi-arid reservoirs. Acta Limnol. Bras. 30:0.

Rooney N, Kalff J, Habel, C, 2003. The role of submerged macrophyte beds in phosphorus and sediment accumulation in Lake Memphremagog, Quebec, Canada. Limnol. Oceanogr. 48:1927-1937.

Rosseel Y, 2012. lavaan: An R package for structural equation modeling. J. Stat. Softw. 48:1-36.

Sampaio EVSB, 2005. [Aproveitamento da macrófita aquática Egeria densa como adubo orgânico].[Article in Portuguese]. Planta Daninha 23:169-174.

Schindler DW, Carpenter SR, Chapra SC, Hecky RE, Orihel DM, 2016. Reducing phosphorus to curb lake eutrophication is a success. Environ. Sci. Technol. 50:8923-8929.

Silvino RF, Barbosa F, 2015. Eutrophication potential of lakes: an integrated analysis of trophic state, morphometry, land occupation, and land use. Braz. J. Biol. 75:607-615.

Soares E, 2013. [Seca no Nordeste e a transposição do rio São Francisco].[Article in Portuguese]. Geografias 9:75-86.

Srivastava J, Gupta A, Chandr, H, 2008. Managing water quality with aquatic macrophytes. Rev. Environ. Sci Biotechnol. 7:255-266.

Tedesco MJ, Gianello C, Bissani C, Bohnen H, Volkweiss SJ, 1995. ]Análise de solo, plantas e outros materiais].[Book in
Portuguese]. Departamento de Solos da Universidade Federal do Rio Grande do Sul: 174 pp.

Tong Y, Zhang W, Wang X, Couture R-M, Larssen T, Zhao Y, Lin Y, 2017. Decline in Chinese lake phosphorus concentration accompanied by shift in sources since 2006 . Nature Geosci. 10:507-511.

Trindade CRT, Pereira SA, Albertoni EF, Palma-Silva C, 2010. [Caracterização e importância das macrófitas aquáticas com ênfase nos ambientes límnicos do Campus Carreiros FURG].[Article in Portuguese]. Cad. Ecol. Aquat. 5:1-22.

Vanderstukken M, Mazzeo N, van Colen W, Declerck SAJ, Muylaert K, 2011. Biological control of phytoplankton by the subtropical submerged macrophytes Egeria densa and Potamogeton illinoensis: a mesocosm study. Freshwater Biol. 56:1837-1849.

Verhofstad MJJM, Alirangues Núñez MM, Reichman,EP, van Donk E, Lamers LPM, Bakker ES, 2017. Mass development of monospecific submerged macrophyte vegetation after the restoration of shallow lakes: Roles of light, sediment nutrient levels, and propagule density. Aquat. Bot. 141:29-38.

Wallsten M, 1980. Effects of the growth of Elodea canadensis Michx. in a shallow lake (Lake Tämnaren, Sweden), p. 139146. In: M. Dokulil, H. Metz and D. Jewson (eds.), Shallow lakes contributions to their limnology. Springer.

Wang L, Liu Q, Hu C, Liang R, Qiu J, Wang Y, 2018. Phosphorus release during decomposition of the submerged macrophyte Potamogeton crispus. Limnology 19:355-366.

Wetzel RG, 1975. Limnology. WB Saunders Co., Philadelphia: $743 \mathrm{pp}$.

Wilson DO, 1972. Phosphate nutrition of the aquatic angiosperm Myriophyllum exalbescens Fern. Limnol. Oceanogr. 17:612616.

Wu Y, Wen Y, Zhou J, Wu Y, 2013. Phosphorus release from lake sediments: Effects of $\mathrm{pH}$, temperature and dissolved oxygen. KSCE J. Civ. Eng. 18:323.

Xing W, Shi Q, Liu H, Liu G, 2016. Growth rate, protein: RNA ratio and stoichiometric homeostasis of submerged macrophytes under eutrophication stress. Knowl. Manag. Aquat. Ecosyst. 25:1-11.

Yu J, Zhong J, Chen Q, Huang W, Hu L, Zhang Y, Fan C, 2018. An investigation of the effects of capping on internal phosphorus release from sediments under rooted macrophytes (Phragmites australis) revegetation. Environ. Sci. Pollut. Res. 25:24682-24694.

Zeng L, He F, Dai Z, Xu D, Liu B, Zhou Q, Wu Z, 2017. Effect of submerged macrophyte restoration on improving aquatic ecosystem in a subtropical, shallow lake. Ecol. Eng. 106:578-587.

Zeng Q, Qin L, Li X, 2015. The potential impact of an interbasin water transfer project on nutrients (nitrogen and phosphorous) and chlorophyll a of the receiving water system. Sci. Total Environ. 536:686-675.

Zhang C, Liu H, Gao X, Zhang H. 2016. Modeling nutrients, oxygen and critical phosphorus loading in a shallow reservoir in China with a coupled water quality Macrophytes model. Ecol. Indic. 66:212-219. 